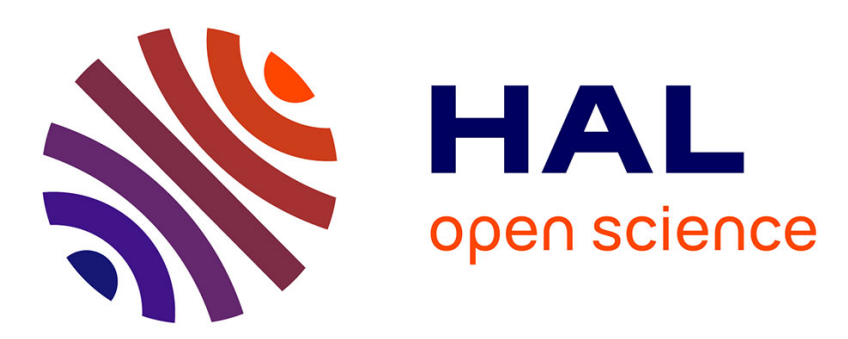

\title{
Modified lignification in the cell walls of cad depressed poplars
}

Arata Yoshinaga, Masahisa Wada, Minoru Fujita, Brigitte Chabbert, Gilles G.

Pilate

\section{- To cite this version:}

Arata Yoshinaga, Masahisa Wada, Minoru Fujita, Brigitte Chabbert, Gilles G. Pilate. Modified lignification in the cell walls of cad depressed poplars. IAWA Journal, 2007, 28 (4), pp.457-471. hal-02655857

\section{HAL Id: hal-02655857 https://hal.inrae.fr/hal-02655857}

Submitted on 29 May 2020

HAL is a multi-disciplinary open access archive for the deposit and dissemination of scientific research documents, whether they are published or not. The documents may come from teaching and research institutions in France or abroad, or from public or private research centers.
L'archive ouverte pluridisciplinaire HAL, est destinée au dépôt et à la diffusion de documents scientifiques de niveau recherche, publiés ou non, émanant des établissements d'enseignement et de recherche français ou étrangers, des laboratoires publics ou privés. 


\title{
MODIFIED LIGNIFICATION IN THE CELL WALLS OF CAD DEPRESSED POPLARS
}

\author{
A. Yoshinaga ${ }^{1}$, M. Wada ${ }^{1}$, M. Fujita ${ }^{1}$, B. Chabbert ${ }^{2}$ and G. Pilate $^{3}$
}

\begin{abstract}
SUMMARY
Ultraviolet microscopic spectrophotometry was used to investigate lignification in the secondary cell walls of wood fibers and vessel elements from either wild type or transgenic poplars with depressed activity of cinnamyl alcohol dehydrogenase (CAD). A distinct shoulder at $330 \mathrm{~nm}$ was characteristic of the transgenic poplar. Measurements performed after 1) a mild alkali treatment or 2) a reduction with sodium borohydride indicated that this shoulder merely resulted from the occurrence of conjugated carbonyl groups in the lignin polymer rather than alkali-soluble cell wall bound phenolic aldehydes. UV absorbance ratios (A330 / A280) measured in the center of secondary walls in the differentiating xylem clearly showed that the structural changes observed in the lignin polymer of transgenic trees occurred very early during lignin deposition. This suggests that, in poplar trees with low CAD activity, cinnamaldehydes are incorporated into lignin even at the early stages of lignification.
\end{abstract}

Key words: Cinnamyl alcohol dehydrogenase (CAD), transgenic poplar, UV microscopic spectrophotometry, transmission electron microscopy, lignification, cell wall, wood fibers, vessel elements.

\section{INTRODUCTION}

Cinnamyl alcohol dehydrogenase (CAD) catalyzes the reduction of cinnamaldehydes into cinnamyl alcohols, which is the last step in the monolignol biosynthesis pathway. Severe reduction of CAD activity was reported in brown-midrib mutants of maize (Halpin et al. 1998) and in a mutant allele of the cad gene in loblolly pine (MacKay et al. 1999). Genetic engineering with an antisense strategy also led to the production of plants with reduced CAD activity, in tobacco (Halpin et al. 1994; Hibino et al. 1995; Yahiaoui et al. 1998a, b), poplar (Baucher et al. 1996) and alfalfa (Baucher et al. 1999).

1) Laboratory of Tree Cell Biology, Division of Forest and Biomaterials Science, Graduate School of Agriculture, Kyoto University, Kitashirakawa-Oiwake-cho, Sakyo-ku, Kyoto 606-8502, Japan [E-mail: A. Yoshinaga: aryosshy@kais.kyoto-u.ac.jp].

2) Parois et Matériaux Fibreux UMR FARE, INRA (Institut National de la Recherche Agronomique), 2 Esplanade R. Garros, BP 224, 51686 Reims, France.

3) Equipe Formation des Parois Lignifiées, Unité Amélioration, Génétique et Physiologie Forestières, INRA-Orléans, Avenue de la Pomme de Pin, BP 20619, Ardon 45166, Olivet Cedex, France. 
The chemical structure of lignin from CAD down-regulated plants was analyzed by Fourier-transformed Infrared and Raman spectroscopy (Stewart et al. 1997), thioacidolysis (Lapierre et al. 1999) and mild alkali hydrolysis (Baucher et al. 1996; Lapierre et al. 1999, 2004), NMR (Kim et al. 2000, 2002, 2003; Akim et al. 2001; Ralph et al. 2001). When CAD is down-regulated, the cinnamaldehydes instead of cinnamyl alcohols may be incorporated into the polymer by radical coupling. Some model experiments also support the incorporation of cinnamaldehydes into lignin by radical coupling (Higuchi et al. 1994; Yahiaoui et al. 1998b; Kim et al. 2000, 2003; Russel et al. 2000). CAD down-regulation also led to an increase in both C6-C1 aldehydes, especially syringaldehyde in mild alkali soluble fraction (Baucher et al. 1996; Lapierre et al. 1999), and free phenolic units, which may ease lignin solubilization and fragmentation during kraft pulping (Lapierre et al. 1999).

The effect of the lignin modifications resulting from low CAD activity were further analyzed with regard to pulping properties (O'Connell et al. 2002), decomposition (Hopkins et al. 2001) and degradability (Bernard-Vailhé et al. 1996, 1998). From the evaluation of field-grown transgenic poplars with low CAD activity, Pilate et al. (2002) demonstrated that the lignin modifications were maintained in the transgenic trees over four years and that one of the reduced-CAD lines had improved characteristics, allowing easier delignification during the pulping process, while using smaller amounts of chemicals and yielding more high-quality pulp. But, until now, the changes in lignin structure resulting from CAD down-regulation has been mainly analyzed in lignin purified extract using destructive assays whereas the lignification process in the cell walls of CAD down-regulated poplars has not yet been described. In this study, we investigated the lignification process in the fiber and vessel secondary walls of CAD down-regulated poplars using in situ UV microscopic spectrophotometry before and after mild alkali hydrolysis or reduction with sodium borohydride.

\section{MATERIALS AND METHODS}

\section{Plant materials}

Genetic transformation has been carried out on a hybrid Populus tremula $\times$ P. alba clone (INRA 717-1-B4) as already described (Leplé et al. 1992). Biochemical characterizations revealed that ASCAD21 transgenic trees were down-regulated for CAD activity (Baucher et al. 1996). In January 1995, poplar microcuttings were acclimatized in the greenhouse and planted in the field (Pilate et al. 2002). In June 1999, five centimeter-thick stem slices were collected from the ASCAD 21 or from the wild type trees and stored into $80 \%$ ethanol. The stems were two years old grown from four-year-old rootstock. The residual CAD activity measured in the ASCAD 21 tree used in this study was only $12 \%$ of the wild type.

\section{Histochemical staining}

In order to detect the occurrence of tension wood, which exhibits unusual lignification pattern particularly in the gelatinous layer, 50- $\mu \mathrm{m}$-thick transverse sections, sprayed on the whole surface of the wood slices, were cut and stained with phloroglucinol-HCl. Then, small blocks were cut from the slice so that they were devoid of tension wood. 
The blocks without tension wood were separated into two categories: 1) the blocks containing differentiating xylem and 2) the blocks containing mature xylem. These two kinds of block from ASCAD 21 line and wild type were dehydrated through an ethanol series and embedded in methyl- and butyl-(1:1, v/v)methacrylate resin.

\section{UV microscopic spectrophotometry on mature xylem}

One- $\mu \mathrm{m}$-thick transverse sections were cut from the embedded mature xylem of ASCAD 21 and wild type trees and placed on quartz slides. The slides were soaked in acetone for one hour to remove the resin from the sections. Then, sections were mounted with glycerin and covered with quartz coverslips.

UV absorption was surveyed in the range of 250 to $400 \mathrm{~nm}$ in $2.5 \mathrm{~nm}$ steps for spot diameter $(0.5 \mu \mathrm{m})$ and a band width of an illuminating monochrometer $(5 \mathrm{~nm}) \mathrm{using}$ a microscopic spectrophotometer (Carl Zeiss MPM 800). UV absorption spectra were measured at the center of the secondary walls of fibers and vessels (noted respectively FSW and VSW) and also at the cell corner middle lamella located between fibers (FFCC). For each cell type (FSW, VSW, and FF-CC), 14 points were selected in the earlywood side, 11 points were selected in the latewood side, and 5 points were selected in the terminal zone where vessel diameters strongly decreased, at the end of each annual ring. UV photomicrographs were also taken at $280 \mathrm{~nm}$ and $330 \mathrm{~nm}$ using a microscopic spectrophotometer (Carl Zeiss UMSP-80).

Sections were eventually treated by drop-wise addition of either 1) 2 M sodium hydroxide for two hours at room temperature to remove phenolic aldehydes incorporated into lignin as reported by Lapierre et al. (1999) or 2) $0.05 \mathrm{M}$ sodium borohydride in $0.03 \mathrm{M}$ sodium hydroxide for one hour at room temperature to reduce cinnamaldehyde groups incorporated in the lignin polymer. A diluted sodium hydroxide $(0.03 \mathrm{M})$ was used for stabilizing sodium borohydride (Marton 1964). After either of these treatments, sections were washed several times in water, dried, mounted with glycerin, and covered with quartz cover slips. UV absorption spectra were recorded after treatment just as described above except for the measuring conditions that were slightly modified for spot diameter $(1.5 \mu \mathrm{m})$ and steps $(2 \mathrm{~nm})$.

\section{Measurement of $U V$ absorbance in the differentiating xylem}

One- $\mu \mathrm{m}$-thick transverse sections were cut from differentiating xylem of both ASCAD 21 and wild type trees. The sections were placed on quartz slides and soaked in acetone for one hour to remove the resin from the sections. The sections were mounted with glycerin, and then covered with quartz cover slips. UV absorption at $280 \mathrm{~nm}$ was measured at the center of developing secondary walls of fibers and vessels in the differentiating xylem for spot diameter $(0.5$ or $1.0 \mu \mathrm{m})$ and a band width of an illuminating monochrometer (20 nm) using the same microscopic spectrophotometer. Measurements were done on 29 points for fibers and 18 points for vessels. UV absorption at $330 \mathrm{~nm}$ was also measured at the same time to detect potential structural changes in the lignin polymer, which appeared as an additional shoulder around $330 \mathrm{~nm}$ in the UV absorption spectrum of the CAD down-regulated poplar samples. Distance from the cambial zone of the individual cell was measured as described in Yoshinaga et al. (1997). 


\section{Transmission electron microscopy of developing secondary walls}

Lignification process of developing cell walls was also observed by transmission electron microscopy after potassium permanganate $\left(\mathrm{KMnO}_{4}\right)$ staining. Ultrathin sections, about $0.1 \mu \mathrm{m}$ thick, were cut from differentiating xylem of both ASCAD 21 and wild type trees. These sections were mounted on Formvar coated copper grids reinforced by carbon. To remove the resin from the sections, the grids were soaked in acetone for 20 min at room temperature. Then the section were stained with $\mathrm{KMnO}_{4}$ as described in Yoshinaga et al. (2004), and observed under a transmission electron microscope (JEOL JEM 1220) at $100 \mathrm{keV}$.

\section{RESULTS AND DISCUSSION}

\section{$U V$ absorption spectra are different in ASCAD21 and wild type trees}

UV absorption spectra were determined in the secondary walls of wood fibers (FSW) and vessel elements (VSW) and also in the cell corner middle lamella between wood fibers (FF-CC) in ASCAD 21 and wild type trees (Fig. 1a-c). These spectra were taken from the earlywood (a), the latewood (b), and the terminal zone (c) of mature xylem and expressed as the average of the different measuring points. In ASCAD 21 line, an additional shoulder around $330 \mathrm{~nm}$ was consistently detected in FSW, VSW and FF-CC, whereas this shoulder was not detected in wild type trees. Second derivatives calculated on UV absorption spectra in ASCAD21 line revealed that the absorption maxima were in the range of 330 to $335 \mathrm{~nm}$. Further analyses revealed that there were no obvious differences between ASCAD 21 and wild type trees in the absorption maxima (Fig. 1d) and the absorbance at the absorption maxima (Fig. 1e). On the contrary, the absorbance ratios (A330/Amax) in Figure 1f were consistently higher in the ASCAD 21 tree (in the range of $0.5-0.6$ in VSW, 0.3-0.4 in FSW, and 0.5-0.8 in FF-CC) than in the wild type tree (in the range of 0.1-0.2 in VSW, FSW and FF-CC). It should be noted that the ratio (A330/Amax) was higher in VSW and FF-CC than FSW. This suggests larger structural lignin modifications in VSW and FF-CC than in FSW.

UV photomicrographs taken at $280 \mathrm{~nm}$ and $330 \mathrm{~nm}$ in wild type (Fig. 2a, b) and ASCAD 21 line (Fig. 2c, d) confirm UV absorption spectra measurements. Indeed, in the wild type, there was almost no absorption in all cell walls at $330 \mathrm{~nm}$ (Fig. 2b), whereas in ASCAD21 line, the absorption at this wavelength was important in the secondary walls of wood fibers and vessel elements and compound middle lamella (Fig. 2d). Chabannes et al. (2001) also observed such an increased absorption around

Figure 1. UV absorption spectra and evaluation of lignification in the mature xylem of ASCAD 21 and wild type trees. - a: spectra from the earlywood side. - b: spectra from the latewood side. - c: spectra from the terminal zone. - d: absorption maxima (mean and SD) of the spectra. e: absorbance at the absorption maxima (mean and SD) of the spectra. - f: absorbance at $330 \mathrm{~nm} /$ absorbance at the absorption maxima (mean and SD) of the spectra. - E: earlywood; L: latewood; T: terminal zone; VSW: vessel secondary walls; FSW: wood fiber secondary walls; FF-CC: cell corner middle lamella between wood fibers. The spectra in $\mathrm{a}-\mathrm{c}$ were expressed as the average of the different measuring points. 

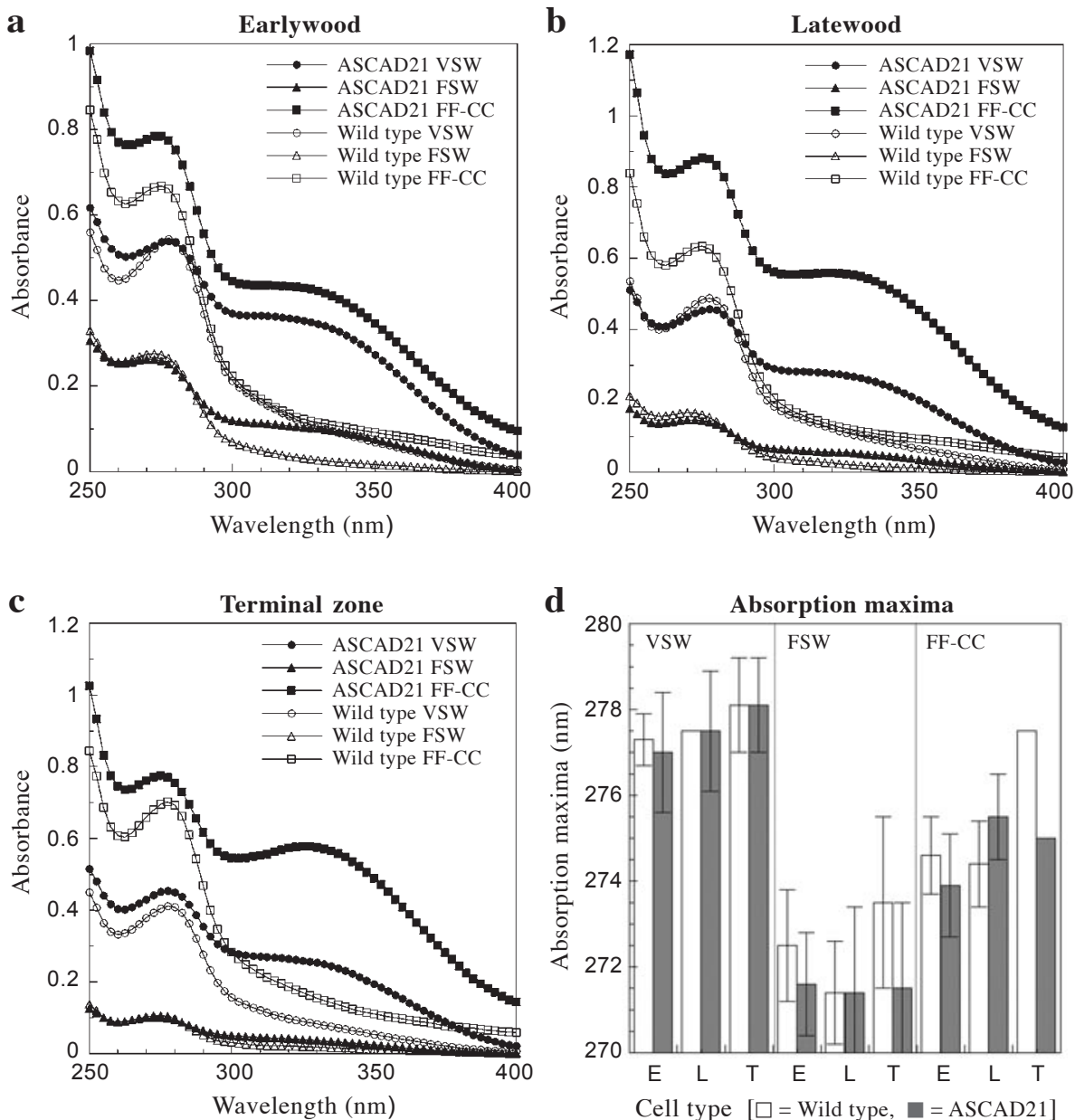

Cell type $[\square=$ Wild type, $\square=$ ASCAD21 $]$
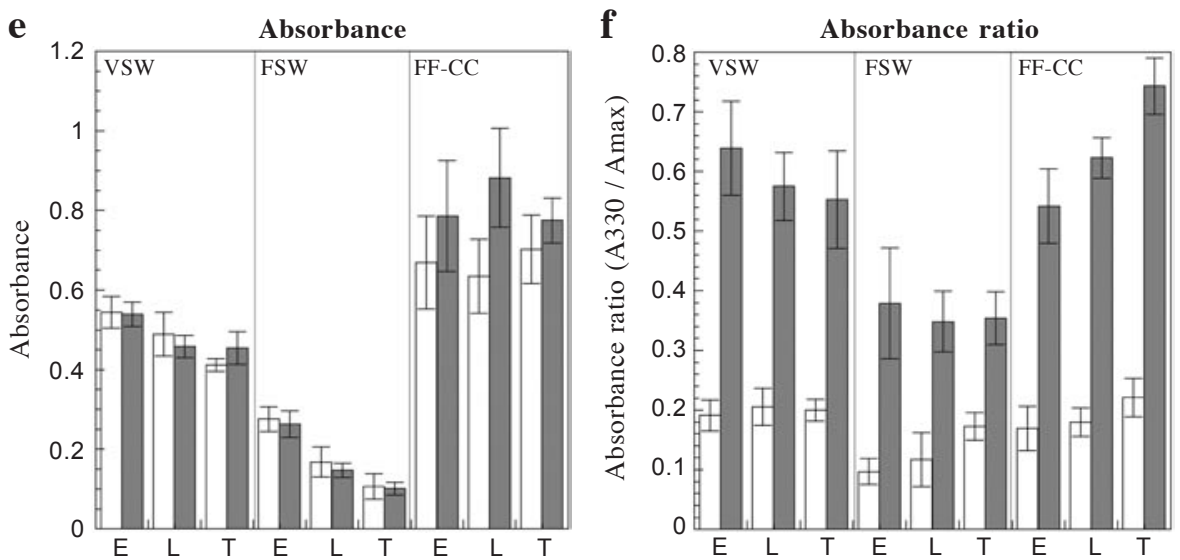

Cell type $[\square=$ Wild type, $\square=$ ASCAD21 $]$

Cell type $[\square=$ Wild type, $\square=$ ASCAD21 $]$ 


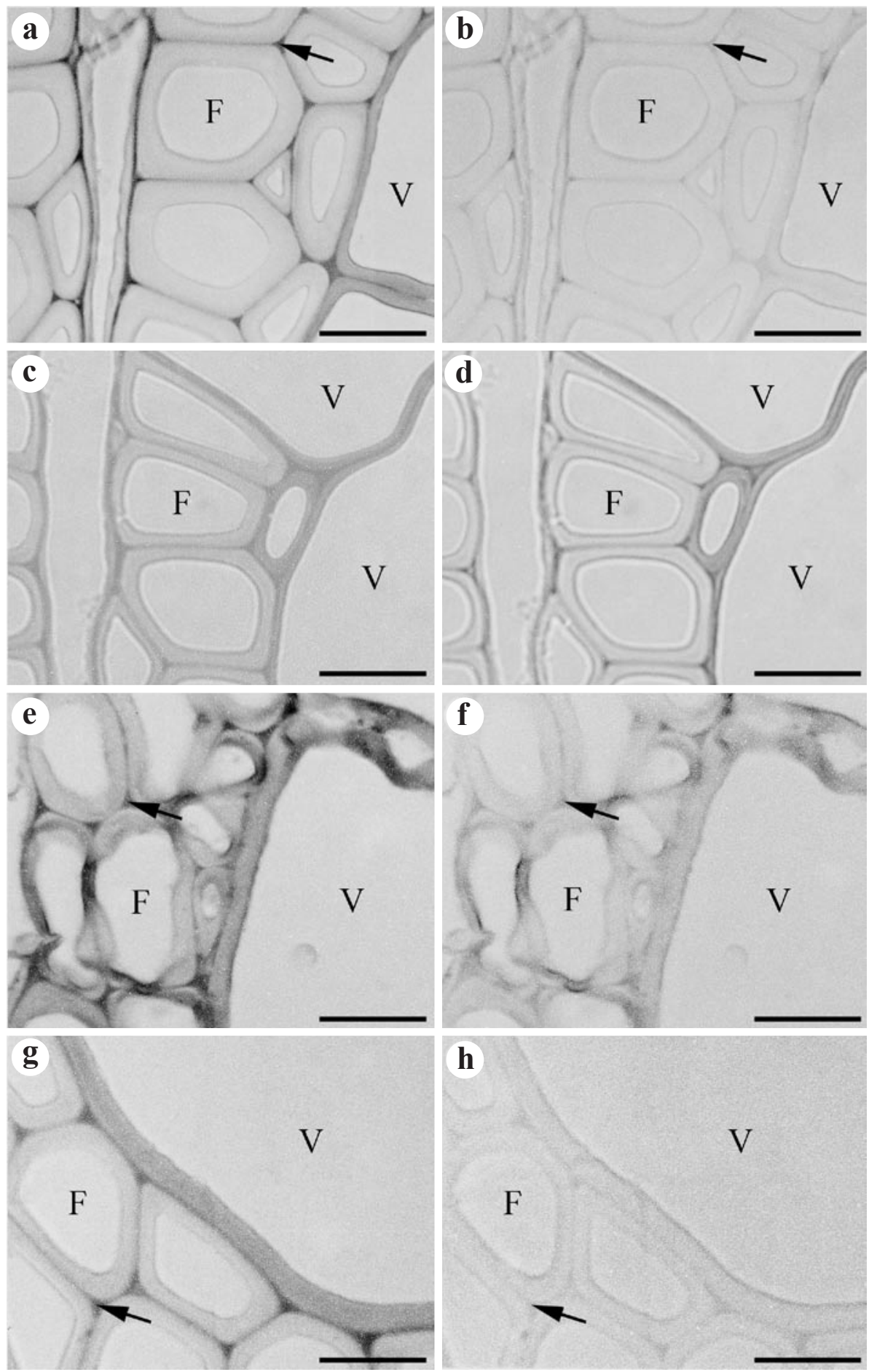


Table 1. The absorption maxima ( $\lambda$ max) and absorbance ratios (A330/Amax) in ASCAD 21 and wild type trees.

\begin{tabular}{|c|c|c|c|c|c|c|c|c|}
\hline \multirow[b]{3}{*}{ Cell type (treatment) } & \multicolumn{4}{|c|}{ Wild type } & \multicolumn{4}{|c|}{ ASCAD 21} \\
\hline & \multicolumn{2}{|c|}{ EW } & \multicolumn{2}{|c|}{ LW } & \multicolumn{2}{|c|}{ EW } & \multicolumn{2}{|c|}{ LW } \\
\hline & $\begin{array}{c}\lambda \max \\
(\mathrm{nm})\end{array}$ & $\begin{array}{l}\text { A } 330 / \\
\text { Amax }\end{array}$ & $\begin{array}{c}\lambda \text { mas } \\
(\mathrm{nm})\end{array}$ & $\begin{array}{l}\text { A300 / } \\
\text { Amax }\end{array}$ & $\begin{array}{c}\lambda \max \\
(\mathrm{nm})\end{array}$ & $\begin{array}{l}\text { A } 330 / \\
\text { Amax }\end{array}$ & $\begin{array}{c}\lambda \max \\
(\mathrm{nm})\end{array}$ & $\begin{array}{l}\text { A } 330 / \\
\text { Amax }\end{array}$ \\
\hline VSW (no treatment) & 278 & 0.202 & 278 & 0.134 & 278 & 0.435 & 276 & 0.635 \\
\hline VSW $\quad(\mathrm{NaOH})$ & 274 & 0.134 & 278 & 0.235 & 278 & 0.453 & 276 & 0.605 \\
\hline VSW $\left(\mathrm{NaBH}_{4}\right)$ & 278 & 0.127 & 276 & 0.148 & 278 & 0.102 & 278 & 0.056 \\
\hline FSW (no treatment) & 276 & 0.083 & 274 & 0.053 & 274 & 0.335 & 274 & 0.641 \\
\hline FSW $\quad(\mathrm{NaOH})$ & 274 & 0.038 & 272 & 0.064 & 270 & 0.489 & 276 & 0.619 \\
\hline FSW $\left(\mathrm{NaBH}_{4}\right)$ & 276 & 0.092 & 274 & 0.062 & 272 & 0.098 & 272 & 0.108 \\
\hline FF-CC (no treatment) & 278 & 0.365 & 280 & 0.259 & 276 & 0.465 & 278 & 0.672 \\
\hline FF-CC (NaOH) & 278 & 0.384 & 282 & 0.431 & 278 & 0.616 & 274 & 0.566 \\
\hline FF-CC $\left(\mathrm{NaBH}_{4}\right)$ & 278 & 0.158 & 278 & 0.218 & 276 & 0.103 & 280 & 0.287 \\
\hline
\end{tabular}

$330 \mathrm{~nm}$ in the xylem of CAD down-regulated tobacco and proposed it resulted from an accumulation of wall bound phenolics whose absorption maximum is in the range of $330 \mathrm{~nm}$.

\section{Effect of a mild alkali treatment on $U V$ absorption spectra}

UV absorption spectra at FSW, VSW and FF-CC in ASCAD21 earlywood and latewood after a mild alkali treatment indicated that the typical absorption shoulder found at around $330 \mathrm{~nm}$ remained mostly unaffected (Fig. 3a, c, e). The absorbance at 280 $\mathrm{nm}$ became higher in FSW and slightly lower in VSW and FF-CC after the treatment. This suggests a different reactivity of FSW against alkali treatment compared to VSW and FF-CC. As illustrated in Figure 2e \& f, deformation appeared more important in FSW than in VSW and FF-CC. This suggests that FSW is more heavily affected by alkali treatment. The increase in the absorbance at $280 \mathrm{~nm}$ in FSW may be due to the removal of some hemicelluloses and/or a change in absorptivity of lignin with alkali. Alternatively, as it is known that the lignin from ASCAD poplar wood is easily removed with alkali, it is also possible that, together with hemicelluloses, some lignin was removed during the alkali treatment in VSW and FF-CC. UV photomicrographs taken at $280 \mathrm{~nm}$ and $330 \mathrm{~nm}$ on ASCAD21 sections after a mild alkali treatment showed that there is still an increased absorption at $330 \mathrm{~nm}$ (Fig. 2d) as compared with wild type (Fig. 2b)

Figure 2. UV photomicrographs of mature xylem in ASCAD21 and wild type trees. - a: wild type at $280 \mathrm{~nm}$. - b: wild type at $330 \mathrm{~nm}$. - c: ASCAD21 line at $280 \mathrm{~nm}$. - d: ASCAD21 line at $330 \mathrm{~nm}$. - e \& f: ASCAD21 line after a mild alkali treatment; e: at $280 \mathrm{~nm}$; f: at $330 \mathrm{~nm}$. g \& h: ASCAD21 line after a reduction with sodium borohydride; g: at $280 \mathrm{~nm}$; h: at $330 \mathrm{~nm}$. - F: wood fibers; V: vessel elements; Arrows: cell corner middle lamella between wood fibers. Scale bars $=20 \mu \mathrm{m}$. 

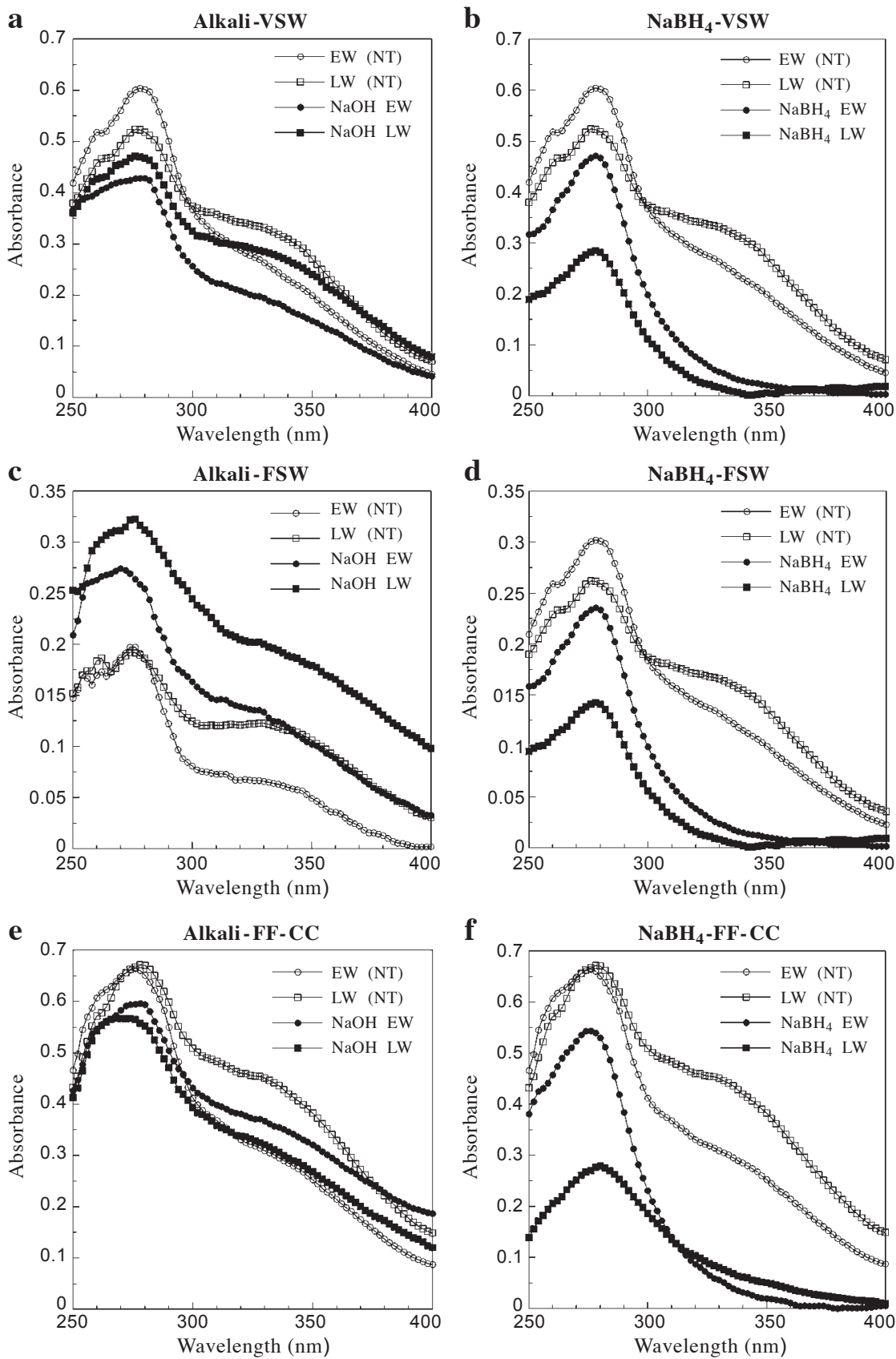

Figure 3. UV absorption spectra of mature xylem in ASCAD21 trees before and after a mild alkali treatment $(\mathrm{a}, \mathrm{c} \& \mathrm{e})$ or a reduction with sodium borohydride $(\mathrm{b}, \mathrm{d} \& \mathrm{f})$. - NT: no treatment. $\mathrm{NaOH}$ : after a mild alkali treatment. $-\mathrm{NaBH}_{4}$ : after a reduction with sodium borohydride. $-\mathrm{EW}$ : earlywood. - LW: latewood. - VSW: vessel secondary walls. - FSW: wood fiber secondary walls. - FF-CC: cell corner middle lamella between wood fibers. 
after a mild alkali treatment in the secondary walls of wood fibers, vessel elements and compound middle lamella (Fig. 2f). Interestingly, the absorbance ratio (A330/Amax) of VSW, FSW and FF-CC in ASCAD 21 poplar (Table 1) increased in earlywood when it slightly decreased in latewood after a mild alkali treatment. In wild type tree, the ratio decreased in VSW and FSW in earlywood, but increased in FF-CC in earlywood as well as in VSW, FSW and FF-CC in latewood. This suggests that the reactivity against alkali treatment may be different in early- and latewood. An increased ratio may result from a change in the absorptivity of lignin (decrease in Amax), whereas a decreased ratio may result either from the removal of substances absorbing at $330 \mathrm{~nm}$ (decrease in A330) or from a change in the absorptivity of lignin (increase in Amax).

We cannot establish a relation between the increased content of phenolic aldehydes (especially syringaldehyde) in the ASCAD21 tree observed by Baucher et al. (1996) and Lapierre et al. (1999) and the typical absorption shoulder that we observed at 330nm in the ASCAD tree, since the conditions of mild alkali treatment used in these studies are different.

\section{Changes in $U V$ absorption spectra after reduction with sodium borohydride}

UV absorption spectra after sodium borohydride treatment at FSW, VSW and FFCC on ASCAD21 sections does not reveal anymore the typical absorption shoulder around $330 \mathrm{~nm}$ and these spectra became very comparable to those recorded on wild type sections (Fig. 3b, d, f). There was no obvious difference in spectral shape in wild type after the treatment (data not shown).

UV photomicrographs taken at $280 \mathrm{~nm}$ and $330 \mathrm{~nm}$ in ASCAD21 line after sodium borohydride treatment confirmed the disappearance of the absorption at $330 \mathrm{~nm}$ in the secondary walls of wood fibers, vessel elements and compound middle lamella (Fig. $2 \mathrm{~g}, \mathrm{~h}$ ). This disappearance was also confirmed by the absorbance ratios (A330/Amax) summarized in Table 1. Sodium borohydride has been used to evaluate the conjugated carbonyl groups in lignin (Chen 1992). The time required for reduction varies according to the type of conjugated carbonyl structures and also with the occurrence of an etherification at the C4 (Adler \& Marton 1959). Our results suggest that there is an increase in conjugated carbonyl groups (cinnamaldehyde or $\alpha$ - or $\beta$-carbonyl groups) in the lignin of ASCAD21 secondary walls of both wood fibers and vessel elements.

There were quite large differences in absorbance at maxima between early- and latewood after the treatment in VSW, FSW and FF-CC (Fig. 3b, d, f). Owing to the fact that lignin from ASCAD poplar is more easily removed with alkali (Baucher et al. 1996), this suggests that weak amounts of lignin may have been removed during the reduction with borohydride thanks to the simultaneous addition of $0.03 \mathrm{M}$ sodium hydroxide. Alternatively, the lignin absorbance may decrease with the reduction of aldehyde groups. Notably, considering that absorbance ratio (A330/Amax) in ASCAD21 (untreated samples) are always lower in earlywood as compared to latewood, one can suggest that the overall decreasing absorbance of lignin in latewood after sodium borohydride treatment would rely on a higher contribution of aldehyde groups as compared to earlywood. Finally, there was no obvious difference in the position of absorption maxima between treated and control samples (Table 1). G-lignin exhibits a maximum 
$\mathbf{a}$
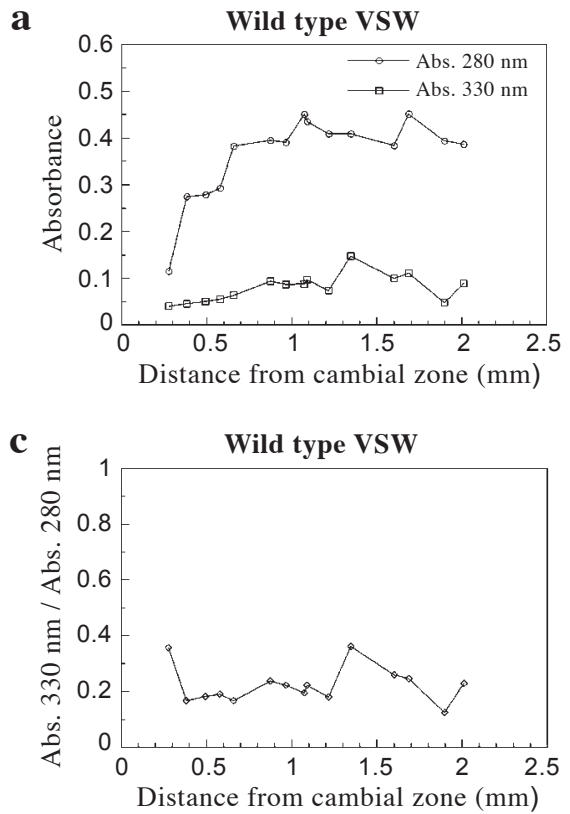

e

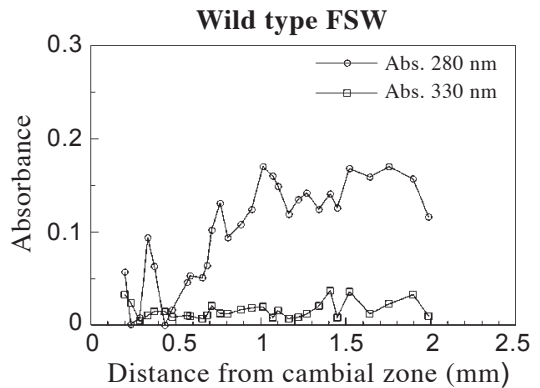

g

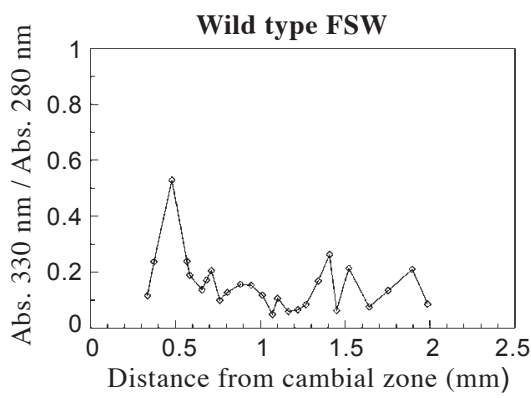

b

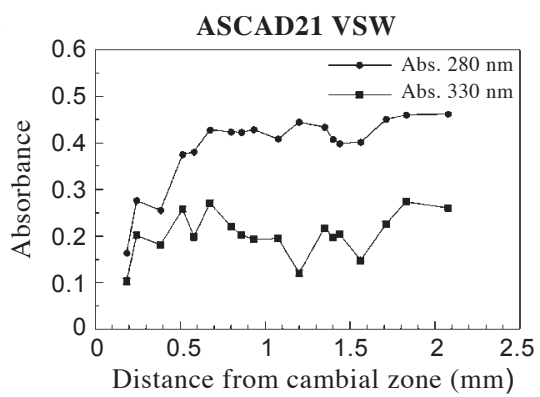

d

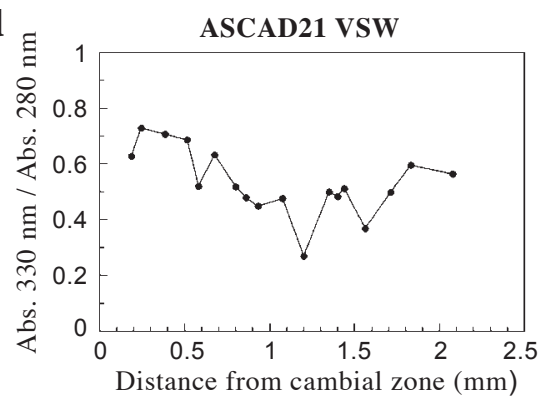

$\mathbf{f}$

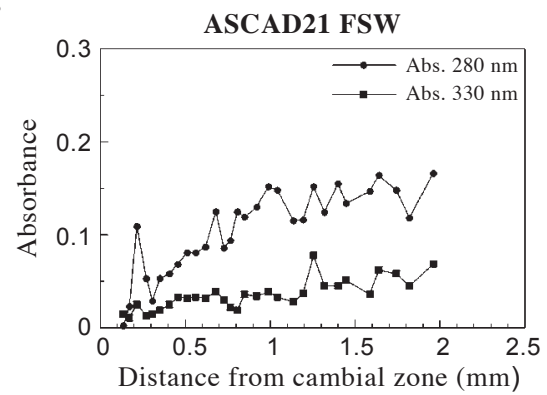

$\mathbf{h}$

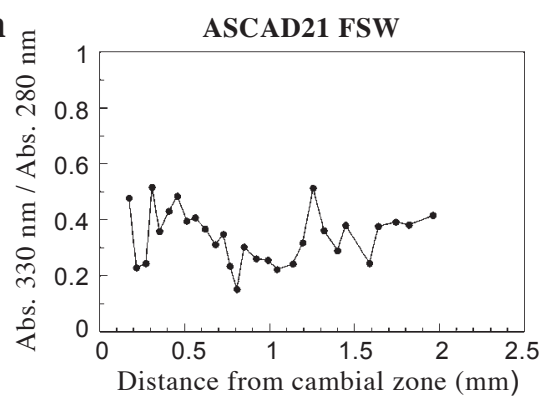

Figure 4. Changes during xylem differentiation in the absorbance at $280 \mathrm{~nm}$ and $330 \mathrm{~nm}$ measured at the center of developing secondary walls and the absorbance ratio (absorbance at $330 \mathrm{~nm} /$ absorbance at $280 \mathrm{~nm}$ ) in ASCAD21 and wild type trees. - a \& c: vessel secondary walls (VSW) in wild type. - e \& g: wood fiber secondary walls (FSW) in wild type. - b \& d: VSW in ASCAD 21 line. $-\mathrm{f} \& \mathrm{~h}$ : FSW in ASCAD 21 line. 
absorbance at $280 \mathrm{~nm}$, whereas the maximum shifts, by 7-10 nm, to a shorter wavelength in syringyl lignin (Fergus \& Goring 1970). Therefore, this result indicates that the content in guaiacyl and syringyl lignins was not affected by the treatment.

\section{Lignification in the differentiating xylem of ASCAD21 and wild type trees}

UV absorbance at $280 \mathrm{~nm}$ and $330 \mathrm{~nm}$ in developing secondary walls of wood fibers and vessel elements in ASCAD21 line and wild type was plotted according to the distance from the cambial zone (Fig. 4). The absorbance at $280 \mathrm{~nm}$ is indicative of the lignification process in the secondary walls whereas the absorbance at $330 \mathrm{~nm}$ is indicative on the extent of the structural differences caused by CAD down-regulation. In the wild type vessel secondary walls (Fig. 4a), the absorbance at $280 \mathrm{~nm}$ increased rapidly to reach a maximum and then remained constant. The absorbance at $330 \mathrm{~nm}$ was also slightly increased to become constant, as well. The absorbance ratio (A330/ A280) was in the range of 0.2-0.3 (Fig. 4c). In ASCAD21 vessel secondary walls (Fig. 4b), the absorbance at $280 \mathrm{~nm}$ and at $330 \mathrm{~nm}$ evolved much like what was observed in the wild type if it was the higher absorbance ratio (in the range of 0.4-0.6) constantly recorded even in the early stage of lignification (Fig 4d).

In the wild type fiber secondary walls (Fig. 4e), the absorbance at $280 \mathrm{~nm}$ increased and became constant whereas the absorbance at $330 \mathrm{~nm}$ remains quite low. In accordance, the absorbance ratio (A330/A280) was in the range of 0.1-0.2 (Fig. 4g). In the ASCAD21 fiber secondary walls (Fig. 4f), the absorbance at $280 \mathrm{~nm}$ and at $330 \mathrm{~nm}$ during xylem differentiation are much comparable to what occurred in the wild type fiber secondary cell walls, with again a higher absorbance at $330 \mathrm{~nm}$, as was generally observed in the samples with low CAD activity. In consequence, the absorbance ratio (A330/A280) was higher than for the wild type (in the range of 0.2-0.4) and almost constant even during the early stage of lignification (Fig. 4h). However, the absorbance ratio for fibers was lower than what was recorded in the vessel secondary walls. In conclusion, the lignification pattern in VSW and FSW appeared similar in wild type and ASCAD21 tree, whereas the lignin structural changes resulting from CAD downregulation were already present in VSW and FSW at the very early stages of lignification.

UV and TEM observation of differentiating xylem did not reveal any obvious difference in the lignification pattern of ASCAD21 and wild type trees (Fig. 5). UV absorption and contrast in TEM were almost similar between ASCAD21 and wild type trees both in lignifying cells (Fig. 5a-d) and in lignified cells (Fig. 5e-h). This is clearly different from what has been previously observed in the fibers of CAD down-regulated tobacco (Takabe et al. 1996) although the residual CAD activity in ASCAD21 poplar

Figure 5. UV and TEM micrographs of differentiating xylem in ASCAD21 and wild type trees. a-d: lignifying cells. - e-h: lignified cells. - a, c, e \& g: wild type. - b, d, f \& h: ASCAD21. a, b, e \& f: UV photographs taken at $280 \mathrm{~nm}$. - c, d, g \& h: TEM micrographs of $\mathrm{KMnO}_{4}$ stained sections. - F: wood fibers; V: vessel elements. - Scale bars are $20 \mu \mathrm{m}(\mathrm{a}, \mathrm{b}, \mathrm{e} \& \mathrm{f})$ and $1 \mu \mathrm{m}$ (c, d, g \& h). 


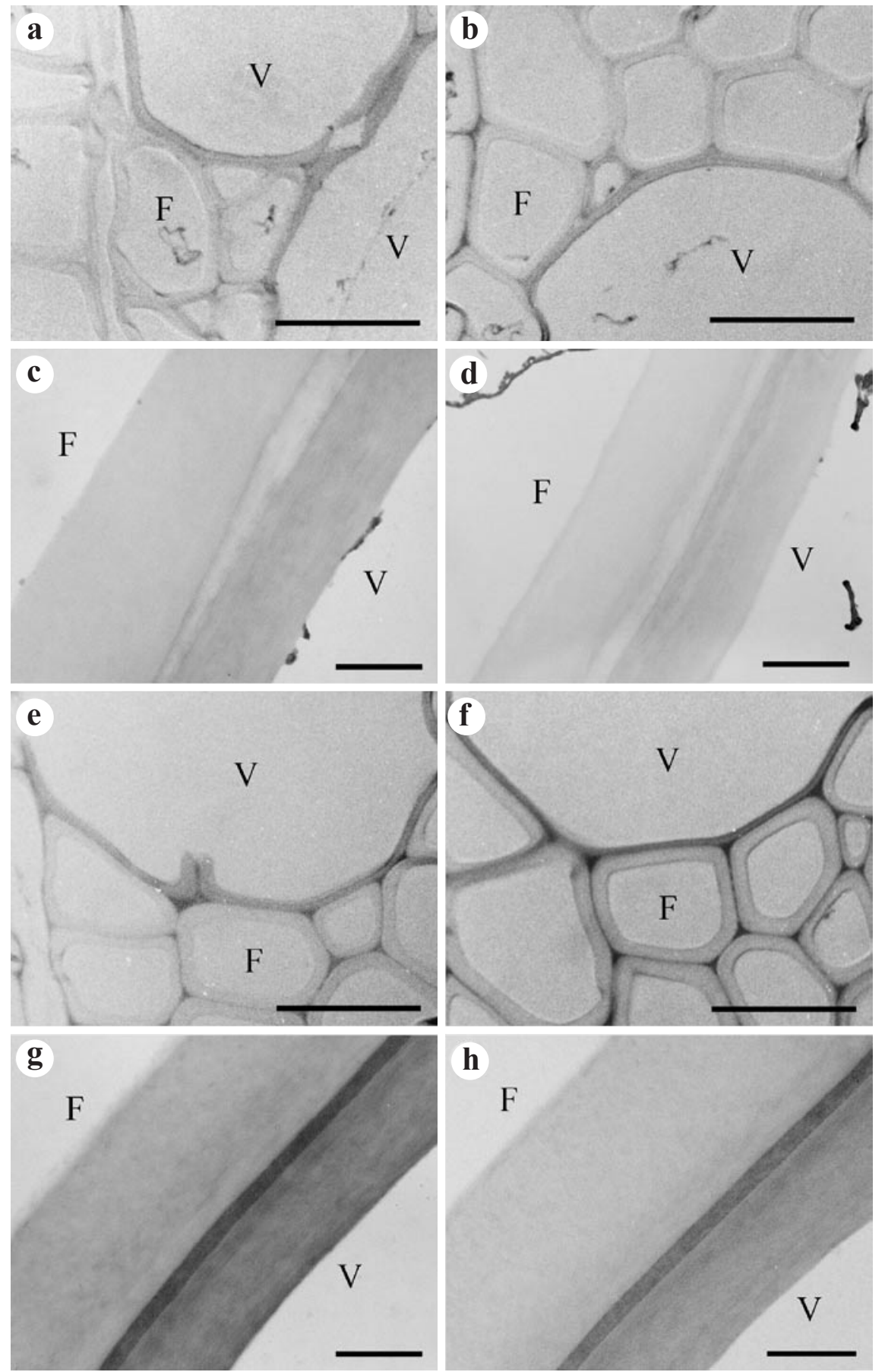

Figure 5; for the legends, see the previous page. 
was lower than that in their CAD down-regulated tobacco. Indeed, these authors have detected strong UV-absorptive substances (electron-opaque materials under TEM) both at the inner surface of the fibre cell walls and in the lumen of vessels. Although we used similar techniques, we were not able to find such substances in ASCAD21 xylem fibers.

\section{CONCLUSION}

In this study, we have demonstrated that the change associated with low CAD activity results in a shoulder at $330 \mathrm{~nm}$ in mature and differentiating xylem in VSW, FSW, and FF-CC. In addition, a higher absorbance ratio has been recorded in ASCAD21 compared to wild type tree during the early stage of lignification in both vessel and fiber secondary walls. Results from sodium borohydride reduction with mature xylem are indicative of an increase in conjugated carbonyl groups in the lignin of the ASCAD21 tree. All these results show that the shoulder is most likely associated to an incorporation of cinnamaldehydes in the lignin polymer, in agreement with Ralph et al. (2001), Kim et al. (2002) and Lapierre et al. (2004).

According to Terashima (1990), lignin from vessels is richer in $\mathrm{G}$ units as well as middle lamellae and cell corners that are the area where lignification begins. However, the changes associated with low CAD activity were consistently detected in FF-CC, FSW and VSW, even during the early steps of secondary wall development. This is not in favor of a differential effect of CAD down-regulation on guaiacyl and syringyl lignin synthesis. Spectral comparison before and after sodium borohydride reduction using coniferyl aldehyde and sinapaldehyde and their polymerization products will be necessary to elucidate any potential differential effect of CAD down-regulation on guaiacyl and syringyl lignin synthesis in ASCAD trees.

In this study, in situ UV microspectrophotometric analysis of cell walls of ASCAD poplar tree demonstrate the incorporation of cinnamaldehydes in the lignin of VSW, FSW and FF-CC, whereas the lignification process in vessel and wood fiber walls did not seem different from what occurs in wild type trees.

\section{REFERENCES}

Adler, E. \& J. Marton. 1959. Zur Kenntnis der Carbonylgruppen in Lignin. I. Acta Chem. Scand. 13: 75-96.

Akim, L.G., D. S. Argyropoulos, L. Jouanin, J.-C. Leplé, G. Pilate, B. Pollet \& C. Lapierre. 2001. Quantitative ${ }^{31}$ P NMR Spectroscopy of lignins from transgenic poplars. Holzforschung 55: 386-390.

Baucher, M., M.A. Bernard-Vailhé, B. Chabbert, J.M. Besle, C. Opsomer, M. Van Montagu \& J. Botterman. 1999. Down-regulation of cinnamyl alcohol dehydrogenase in transgenic alfalfa (Medicago sativa L.) and the effect on lignin composition and digestibility. Plant Molecular Biol. 39: 437-447.

Baucher, M., B. Chabbert, G. Pilate, J. Van Doorsselaere, M.T. Tollier, M. Petit-Conil, D. Cornu, B. Monties, M. Van Montagu, D. Inzé, L. Jouanin \& W. Boerjan. 1996. Red xylem and higher lignin extractability by down-regulating a cinnamyl alcohol dehydrogenase in poplar. Plant Physiol. 112: 1479-1490. 
Bernard-Vailhé, M.A., J.M. Besle, M.P. Maillot, A. Cornu, C. Halpin \& M. Knight. 1998. Effect of down-regulation of cinnamyl alcohol dehydrogenase on cell wall composition and on degradability of tobacco stems. J. Sci. Food Agric. 76: 505-514.

Bernard-Vailhé, M. A., A. Cornu, D. Robert, M.P. Maillot \& J.M. Besle. 1996. Cell wall degradability of transgenic tobacco stems in relation to their chemical extraction and lignin quality. J. Agric. Food Chem. 44: 1164-1169.

Chabannes, M., K. Ruel, A. Yoshinaga, B. Chabbert, A. Jauneau, J.P. Joseleau \& A.M. Boudet. 2001. In situ analysis of lignins in transgenic tobacco reveals a differential impact of individual transformations on the spatial patterns of lignin deposition at the cellular and subcellular levels. Plant J. 28: 271-282.

Chen, C.L. 1992. Determination of carbonyl groups. In: S.Y. Lin \& C.W. Dence (eds.), Methods in lignin chemistry: 446-457. Springer-Verlag, Berlin, Heiderberg.

Fergus, B. J. \& D.A.I. Goring. 1970. The location of guaiacyl and syringyl lignins in birch xylem tissue. Holzforschung 24: 113-117.

Halpin, C., K. Holt, J. Chojecki, D. Oliver, B. Chabbert, B. Monties, K. Edwards, A. Barakate \& G.A. Foxon. 1998. Brown-midrib maize (bm1) - a mutation affecting the cinnamyl alcohol dehydrogenase gene. Plant J. 14: 545-553.

Halpin, C., M.E. Knight, G. A. Foxon, M.M. Campbell, A.M. Boudet, J.J. Boon, B. Chabbert, M.T. Tollier \& W. Schuch. 1994. Manipulation of lignin quality by downregulation of cinnamyl alcohol dehydrogenase. Plant J. 6: 339-350.

Hibino, T., K. Takabe, T. Kawazu, D. Shibata \& T. Higuchi. 1995. Increase of cinnamaldehyde groups in lignin of transgenic tobacco plants carrying an antisense gene for cinnamyl alcohol dehydrogenase. Biosci. Biotech. Biochem. 59: 929-931.

Higuchi, T., T. Ito, T. Umezawa, T. Hibino \& D. Shibata. 1994. Red-brown color of lignified tissues of transgenic plants with antisense CAD gene: wine-red lignin from coniferyl aldehyde. J. Biotechnol. 37: 151-158.

Hopkins, D.W., E. A. Webster, J.A. Chudek \& C. Halpin. 2001. Decomposition in soil of tobacco plants with genetic modifications to lignin biosynthesis. Soil Biol. Biochem. 33: 14551462.

Kim, H., J. Ralph, F. Lu, G. Pilate, J.C. Leplé, B. Pollet \& C. Lapierre. 2002. Identification of the structure and origin of thioacidolysis marker compounds for cinnamyl alcohol dehydrogenase deficiency in angiosperms. J. Biol. Chem. 277: 47412-47419.

Kim, H., J. Ralph, F. Lu, S.A. Ralph, A. M. Boudet, J. J. MacKay, R.R. Sederoff, T. Ito, S. Kawai, H. Ohashi \& T. Higuchi. 2003. NMR analysis of lignins in CAD-deficient plants. Part 1. Incorporation of hydroxycinnamaldehydes and hydroxybenzaldehydes into lignins. Org. Biomol. Chem. 1: 268-281.

Kim, H., J. Ralph, N. Yahiaoui, M. Pean \& A.M. Boudet. 2000. Cross-coupling of hydroxycinnamyl aldehydes into lignins. Org. Lett. 2: 2197-2200.

Lapierre, C., G. Pilate, B. Pollet, I. Mila, J.C. Leplé, L. Jouanin, H. Kim \& J. Ralph. 2004. Signitures of cinnamyl alcohol dehydrogenase deficiency in poplar lignins. Phytochemistry 65: 313-321.

Lapierre, C., B. Pollet, M. Petit-Conil, G. Toval, J. Romero, G. Pilate, J.C. Leplé, W. Boerjan, V. Ferret, V. De Nadai \& L. Jouanin. 1999. Structural alterations of lignins in transgenic poplars with depressed cinnamyl alcohol dehydrogenase or caffeic acid O-methyltransferase activity have an opposite impact on the efficiency of industrial kraft pulping. Plant Physiol. 119: 153-163.

Leplé, J.C., A.C.M. Brasileiro, M.F. Michel, F. Delmotte \& L. Jouanin, 1992. Transgenic poplars: expression of chimeric genes using four different constructs. Plant Cell Rep. 11: 137-141.

MacKay, J., T. Presnell, H. Jameel, H. Taneda, D. O’Malley \& R. Sederoff. 1999. Modified lignin and delignification with a CAD-deficient loblolly pine. Holzforschung 53: 403-410. 
Marton, J. 1964. On the structure of kraft lignin. Tappi 47: 713-719.

O'Connell, A., K. Holt, J. Piquemal, J. Grima-Pettenati, A.M. Boudet, B. Pollet, C. Lapierre, M. Petit-Conil, W. Schuch \& C. Halpin. 2002. Improved paper pulp from plants with suppressed cinnamyl-CoA reductase or cinnamyl alcohol dehydrogenase. Transgenic Research 11: 495-503.

Pilate, G., E. Guiney, K. Holt, M. Pettit-Conil, C. Lapierre, J.C. Leplé, B. Pollet, I. Milla, E.A. Webster, H.G. Marstorp, D.W. Hopkins, L. Jouanin, W. Boerjan, W. Schuch, D. Cornu \& C. Halpin. 2002. Field and pulping performances of transgenic trees with altered lignification. Nature Biotechnology 20: 607-612.

Ralph, J., C. Lapierre, J.M. Marita, H. Kim, F. Lu, R.D. Hatfield, S. Ralph, C. Chapple, R. Franke, M.R. Hemm, J. Van Doorsselaere, R.R. Sederoff, D.M. O’Malley, J.T. Scott, J.J. MacKay, N. Yahiaoui, A.M. Boudet, M. Pean, G. Pilate, L. Jouanin \& W. Boerjan. 2001. Elucidation of new structures in lignin of CAD- and COMT-deficient plants by NMR. Phytochemistry 57: $993-1003$.

Russel, W.R., G.J. Provan, M. J. Burkitt \& A. Chesson. 2000. Extent of incorporation of hydroxycinnamaldehydes into lignin in cinnamyl alcohol dehydrogenase-downregulated plants. J. Biotechnol. 79: 73-85.

Stewart, D., N. Yahiaoui, G. J. McDougall, K. Myton, C. Marque, A.M. Boudet \& J. Haigh. 1997. Fourier-transform infrared and raman spectroscopic evidence for the incorporation of cinnamaldehydes into the lignin of transgenic tobacco (Nicotiana tabacum L.) plants with reduced expression of cinnamyl alcohol dehydrogenase. Planta 201: 311-318.

Takabe, K., H. Saiki, D. Shibata \& T. Hibino. 1996. Histochemical observation on transgenic tobacco with an anti-sense CAD gene. In L.A. Donaldson et al. (eds.), Recent advances in wood anatomy: 231-236. New Zealand Forest Research Institute Ltd., New Zealand.

Terashima, N. 1990. A new mechanism for formation of a structurally ordered protolignin macromolecule in the cell wall of tree xylem. J. Pulp Paper Sci. 16: J150-J155.

Yahiaoui, N., C. Marque, H. Corbière \& A.M. Boudet. 1998a. Comparative efficiency of different constructs for down regulation of tobacco cinnamyl alcohol dehydrogenase. Phytochemistry 49: 295-306.

Yahiaoui, N., C. Marque, K.E. Myton, J. Negrel \& A.M. Boudet. 1998b. Impact of different levels of cinnamyl alcohol dehydrogenase down-regulation on lignins of transgenic tobacco plants. Planta 204: 8-15.

Yoshinaga, A., M. Fujita \& H. Saiki. 1997. Secondary wall thickening and lignification of oak xylem components during latewood formation. Mokuzai Gakkaishi 43: 377-383.

Yoshinaga, A., S. Ohno \& M. Fujita. 2004. Delignification of cell walls of Chamaecyparis obtusa during alkaline nitrobenzene oxidation. J. Wood Sci. 50: 287-294. 